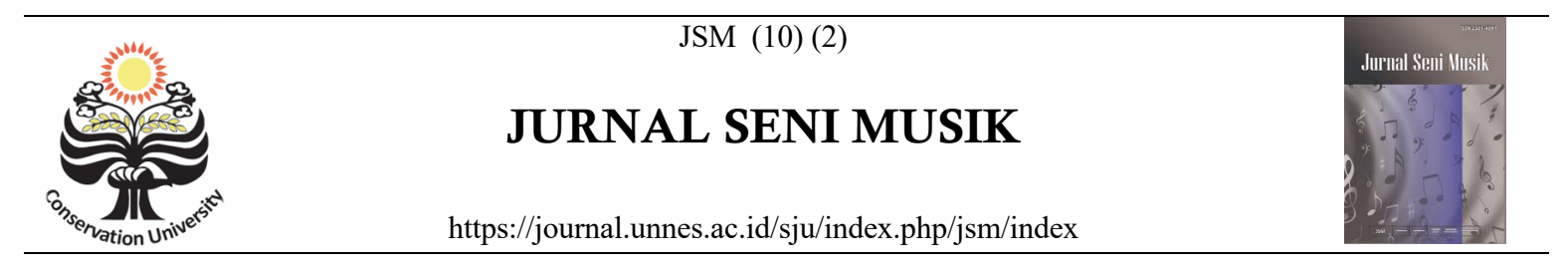

\title{
The Revitalization Of Badrasanti's Literary Work In The Form Of Musical Performances
}

\author{
Diana Elvira Ochtaviani \\ Universitas Negeri Semarang \\ Widodo ${ }^{{ }^{1}}$ \\ Universitas Negeri Semarang
}

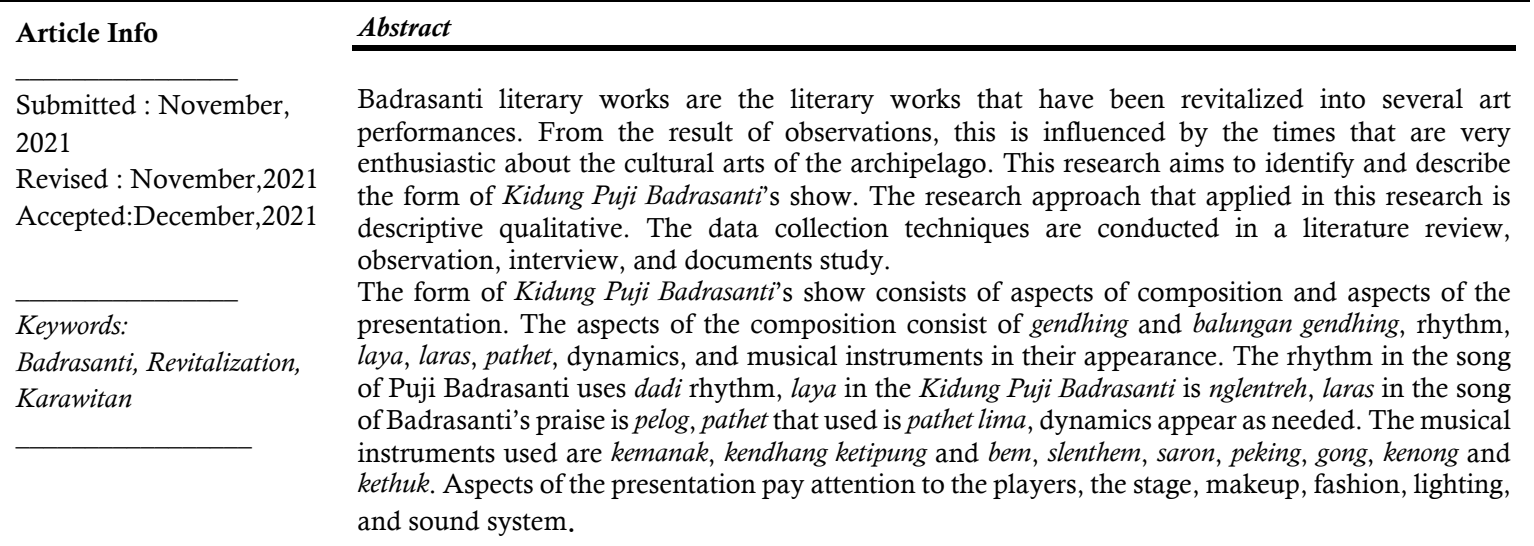

\begin{tabular}{lr}
\hline Corresponding Author: & ISSN 2503-2860 \\
Email : 1.widodo_bsejati@mail.unnes.ac.id &
\end{tabular}




\section{INTRODUCTION}

Badrasanti is a literary work in Central Java that uses the language of the Ngoko Javanese coastal shaped the song text concatenation which has special metered at the beginning of the process of Islamization of the Java Island of the year 1604 Saka. That book saves the history data of the various aspects of community life on the Java coast. That literature work contains a lot of the teachings of the primacy of life that reeks of Java's Buddha. The description of the teachings on the song text of Badrasanti is separated according to the theme discussed, each theme is discussed in some of the verses of the song (Santibadra, 1966: 10). The existence of literature works Badrasanti never be banned from spreading since the colonial era until the new order era, the prohibition such a charge is the doctrine that contains a lot of controversies that had a different understanding of people's beliefs in general (Santibadra, 1966: 21). Since 2012, literature works began to revolve in the wider community, especially among Buddhists.

The process in developing the literature of Badrasanti spearheaded by the young figure of Semarang City, Wahyudi Agus Riyanto and Gusti Ayu Ruskartiko as Buddhist, a form of the revitalization of the literary work which disseminated not only in the form of reprints of Badrasanti's literature work but also some variety of artworks show in creation based on the content of the text on Badrasanti's literary works. The development of Badrasanti's literary works, Wahyudi makes the activity center of the revitalization of Badrasanti's literary works in the form of the Badrasanti Foundation.

Steps in the process of developing Badrasanti's literary works in the form of artworks are looking at the characteristics of the contents of Badrasanti literary writing, the provision of songs on Badrasanti texts in the form of Kidung Puji Badrasanti, the creation of work on Kidung Puji Badrasanti, and the making gendhing-gendhing of Kidung Puji Badrasanti. Some of Badrasanti's musical compositions are used as karawitan supporting dance works based on the themes inside Badrasanti's text. Some of Badrasanti's dances that have been created are Ngracut dance and Pambuka dance.

Revitalization is a process or way and action to revive something that was considered important that was previously deceived. According to (Ilahi: 2009) The revitalization of traditional performing arts is intended to explore and give new meaning to the art without having to change its substance and form, if the performing arts used to function magically or as entertainment in the implementation of traditional ceremonies of the local community, then in the current context the function needs to be adjusted to the changing times, for example as a cultural tourist attraction.

The revitalization of Badrasanti's literary work was originally initiated by Wahyudi Agus Riyanto, a Buddhist who is active in the Buddhist assembly in Semarang City, because the religion he embraced does not yet have certain cultural arts characteristics that are nuanced local Javanese. During this time, Buddhism is better known as a religion with a Chinese style, such as the celebration of Vesak colored by Imlek or Chinese-new-year, Cap Go Meh, and Barongsai.

In 2012 Wahyudi found several old libraries that were considered useless, one of which was badrasanti literary work. After reading and knowing the contents, Wahyudi felt that the book was very important for Javanese Buddhist people who live in coastal areas. In general, the content is noble teaching for the Javanese Buddhist community, in addition to the important history of the journey of the Indonesian nation, friendship between Javanese and Chinese, and advice on Buddhist patterns is also contained in the library. Badrasanti's literary work has for some time been inhibited by certain circles because its contents are considered contrary to the understanding of the wider community, if this literary work is spread then it is feared that it can disrupt the harmony of the social life of Javanese people. 
In 2014 Wahyudi began the process of revitalizing Badrasanti's literary work assisted by an academic cultural artist in PAKARJAWI named Widodo Brotosejati. The literary work of Badrasanti. Badrasanti's literary text continues to be revitalized in various forms of performance art until now so that the work is again known and widespread in the community. The noble teachings contained in the literary work can be understood by the wider community. Badrasanti Foundation cooperates with Pakumpulan Paguyuban Karawitan Jawa Indonesia (PAKARJAWI) by involving literary experts, karawitan experts, and tembang (song) experts. According to Susetyo (2007: 4), the form of the show is divided into two, namely the form of composition and the form of presentation. The form of musical composition consists of: 1) rhythm; 2) melody; 3) harmony; 4) poetry; 5) Tempo; 6) Dynamic; 7) expression; 8) instrument arrangement. While the form of presentation 1) the order of presentation; 2) stage layout; 3) makeup; 4) fashion; 5) sound system; 6) The lighting. The form of the revitalization of Badrasanti's literary works into a variety of performance artworks such as tembang waosan, Garap kemanakan, dance, ketoprak, and wayang.

\section{METHOD}

This study uses qualitative descriptive methods because researchers analyze data objectively based on facts and then the results of the study are presented in the descriptive form containing the Revitalization of Badrasanti Literary Works in the Form of Musical Performances.

The data collection techniques used are observation, interviews, and documentation. Observations were made at the $14^{\text {th }}$ cultural activity named setu wagen on May 29, 2019, at the Pakarjawi secretariat, interviews were conducted with two sources in this study, namely the chairman of badrasanti Foundation named Wahyudi Agus Riyanto and the creator of Badrasanti's praise gendhing named Widodo Brotosejati, documentation was carried out by looking at several video archives and photos of the training process and the creative process of revitalizing Badrasanti's literary work seen from the aspect of composition and performance.

\section{RESULTS AND DISCUSSIONS}

\section{A Brief History of Badrasanti}

Badrasanti is a work of Jawa Tengahan literature that speaks Kawi and written by Mpu Santibadra in Lasem mountain in 14001401 Saka. At the time of Adipati Lasem Pangeran Tejakusuma I was composed Badrasanti still with the same form of Badrasanti Word in 1502 Saka on the orders of Sultan Pajang Bagus Tingkir who is still a descendant of Mpu Santibadra. In 1604 Saka, Adipati Lasem Pangeran Tejakusuma IV updated the Badrasanti manuscript from Tejakusuma I using dluwang dedak paper and Javanese script using the general Javanese language at that time, namely Jawa Tengahan. The latest Badrasanti prints were made in 1967 AD as many as 586 sloka by Ramadharma S Reksowardojo, then equipped up to 1360 sloka by Raden Panji Tarkip Hadidarsana as a descendant (trah) of Tejakusuma Lasem in 1985 AD (Santibadra, 1966: 18).

\section{Structural Features}

Badrasanti has a unique paugeran or benchmark that is fundamental to Buddhist philosophy, the benchmark is that in one temple there are two krompols (krompol) or two parts which are three rows each multiplied by two, in two krompol it shows Hyang Kadharpa or father and mother who are fused in one temple, each krompol consisting of three lines has the meaning of Tri Ratna namely: Buddha, Dharma, Sangha, there are twelve syllables in one line, each line consisting of two pause groups, consisting of four syllables and eight syllables according to (Sabda Badrasanti, 1966: 5). Here is an example of a text by Badrasanti's literary work: 
Yen wong Buddha jodhon wayuh tan prayoga Saben dina wong wayuh tambah rekasa Entuk suka, katentreman mandar sirna Sapa wayuh pikire sangsaya kisruh Tambah ewuh semrawut nanjake butuh Yen wes sepuh repote sangsaya wuwuh The translation

For Buddhists, polygamy is not recommended because it is not good.

Every day polygamous people suffer more and more.

If you have fun, peace will be destroyed.

Who is the polygamous mind getting ruined It will be more difficult in managing finances or needs

After old age, it will grow even more.

\section{Text Content}

The content of Badrasanti's literary work is divided into 27 chapters, each chapter discussing different themes. Here are each chapter of the contents of Badrasanti's literary work: 1) Pudji (Praise); 2) Jejodhowan (Matchmaking); 3) Anak Turun (Child Down); 4) Wong Tuwa (Parents); 5) Sedulur (Family); 6) Cancan; 7) Mangan Ngombe (Eat and Drink); 8) Nyandhang Menganggo (Wear Using); 9) Galang Omah (Home Buffer); 10) Bandha (Possessions); 11) Papan Plemahan (Plemahan Board); 12) Duwe Gawe (Having Event); 13) Seni Budaya (Cultural Arts); 14) Alam (Nature); 15) Awak Pribadi (Self Personal); 16) Adat Pranata (Pranata Custom); 17) Kanyatan Agung Papat; 18) Marang Agung Wolu; 19) Pangerten; 20) Pikiran Utami (Main Thought); 21) Pangucap Utama (Main Speech); 22) Pakarti Utama; 23) Nyambut Gawe (Work); 24) Ikhtiar Utami (Main Initiative); 25) Kawigaten Sayekti; 26) Semadi; 27) Penutup (Closing).

Badrasanti's literary work was revitalized or re-reworked by a group of artists in Pakarjawi into a form of art. The form of the artwork: tembang waosan, garap kemanakan, dance music, Ketoprak, and wayang. Here is the description of the form of the revitalization of Badrasanti's literary work.

\section{Tembang Waosan}

Tembang waosan can be interpreted as a developed reading. Revitalization of Badrasanti's literary work in the form of tembang waosan is divided into three parts, namely: laras slendro pathet manyura, laras slendro pathet sanga, and laras pelog pathet nem. Each of this tembang waosan is special metered Badrasanti. The technique of cengkok on tembang waosan Kidung Puji Badrasanti is already tied to the notation song. The rhythm used in Badrasanti praise depends on each sindhen (singer) or self-tinging in chanting it. The function of tembang waosan of Kidung Puji Badrasanti is to convey the contents of the literary text in the form of waosan or readings that are developed.

\section{Notation 1.1: Kidung Puji Badrasanti Laras Slendro Pathet Manyura}

\section{Kidung puji Badrasanti laras slendro pathet Manyura}

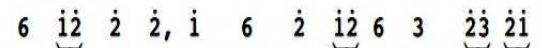

Sa-ma-di-ya nge -ning ke ra-sa-ning dri - ya

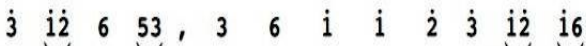

$A$ - sih tres-na ma-rang sa-gung ing du-ma-dya,

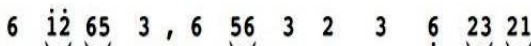

Ku- li- nak na sun no-ra ma-ham-beg si-ya.

$\begin{array}{llllllllllll}1 & 212 & 3 & 3,6 & \text { i2 } & 6 & 5 & 6 & 2 & 56 & 53\end{array}$

$D a-\tan n g a n-t i$ sa-ma-di kang tan pra-yo-gi,

$\begin{array}{llllllllllll}3 & 6 & \mathrm{i} & \mathrm{i}, & \dot{3} & \mathrm{i} & 6 & \mathrm{i} & 6 & 3 & 25 & 32\end{array}$

Mung si-nu-rung leng - ing $a-t i$ sre - $i$ dreng-ki,

$\begin{array}{lllllllllllll}6 & 56 & 32 & 1 & \overline{3} & 3 & 56 & \overline{56} & \overline{.2} & 1 & \overline{21} & 6\end{array}$

$M a$ - neh ben-ci ma-rangli- yan nga-jabpa-ti. 


\section{Notation 1.2: Kidung Puji Badrasanti Laras Slendro Pathet Sanga}

\section{Kidung puji Badrasanti, laras Slendro pathet Sanga}

$\begin{array}{llllllllllll}2 & 5 & 6 & \mathrm{i} & 6 & 5 & \mathrm{i} & 6 \mathrm{i} & 5 & 3 & 26 & 6\end{array}$ Yen wong Bu-ddha jo-dhon wa- yuh tan pra-yo-go

i $\quad \begin{array}{rllllllllll}6 \dot{1} & 5 & 32 & 2 & 5 & 6 & 6 & 5 & 6 & \underset{6}{6 i} & 65\end{array}$

Sa - ben di - na 'wong wa- yuh tam - bah re - ka - sa

$\begin{array}{llllllllllll}5 & 6 \mathrm{i} & 5 & 2 & 5 & 35 & 2 & 1 & 2 & 5 & 12 & \underbrace{16}\end{array}$

En- tuk su-ka ka-ten-tre - man man-dar sir-na

$\begin{array}{llllllllllll}1 & 61 & 5 & 2 & 1 & 6 & 6 & 6 & 6 & 1 & 2 & 2\end{array}$

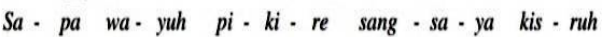

$\begin{array}{llllllllllll}5 & 5 & 565 & 32 & 2 & 2 & 2 & 2 & 1 & 12 & 61 & 1\end{array}$ Tam-bah $e \cdot w u h$ su-mra-wut nan-jak $\cdot k e \quad b u \cdot t u h$

$\begin{array}{llllllllllll}5 & 35 & 21 & 6 & 6 & 1 & 2 & 2 & 1 & 12 & 61 & 65\end{array}$

Yen wis se - puh re - pot.e sang - sa.ya wu-wuh

Notation 1.3: Kidung Puji Badrasanti Laras Pelog Pathet Nem

\section{Kidung puji Badrasanti Laras Pelog pathet Nem}

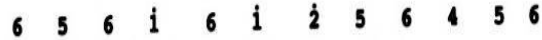

Yen wong Bu-ddha jo-dhon wa-yuh tan pra-yo-ga

$6564245656 \underbrace{121} \underbrace{65}$

Sa ben di-na wong wa-yuh tam-bah re $k a \cdot s a$

$i \dot{i} i \dot{i} 6 i \underbrace{i 2} \underbrace{56} 1 \underbrace{232} \underbrace{16}$

En-tuk su-ka ka-ten-trem-an man-dar sir - na

$\begin{array}{lllllllllllll}6 & 1 & 2 & 2 & 4 & 5 & 5 & 5 & 6 & 4 & 5 & 2\end{array}$

$\mathrm{Sa} \cdot \mathrm{pa}$ wa-yuh pi-kir-e sang-sa-ya kis-ruh

24566 i 11665645

Tam-bah e-wuh su-mra-wut nan-jak-ke bu - tuh

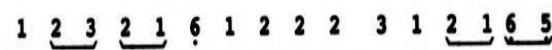

Yen wis se - puh re-pot-e sang-sa-ya wu - wuh

\section{Garap Kemanakan}

Garap kemanakan of the Kidung Puji Badrasanti has patterns that can be categorized as a form of "Ketawang Gendhing" by paying attention to the pattern of the tabuhan of the kendang kalih instrument (kendang ketipung and kendang bem), kethuk, kenong, and gong, as a structural ricikan or gamelan instrument that plays the structural patterns of a gendhing. Ketawang Gendhing's formula in Kidung Puji Badrasanti is 1 gongan consisting of 32 sabetan that have a pattern, 2 tabuhan kenong on the $16^{\text {th }}$ and $32^{\text {nd }}$ sabetan, there are 4 tabuhan kethuk on the $4^{\text {th }}$ sabetan, 12, 20, 28. Kidung Puji Badrasanti in the context of the pattern of Garap kemanakan related to the dynamics raised as needed. Cengkok and wiled in the song are already related to the pattern of the song. Laya on gendhing Badrasanti's praise tends to be nglentreh or relatively slow and uses dadi rhythm because the rhythm can improve the sacred and majestic atmosphere.

\section{Notation 1.4: Kidung Puji Badrasanti Laras} Pelog Pathet Lima Garap Kemanakan

Kidung puji Badrasanti, laras pelog pathet lima Garap Kemanakan

$$
\begin{aligned}
& \text { ‥ } \overline{61} 2 \overline{.53} \overline{23} 1 \text {. . } \overline{61} 2 \overline{.31} \overline{26} 5 \\
& \text { De-mi Bud-dha Gu-ru Gung Pam-ba-bar Dhar-ma } \\
& \text {. . } \underbrace{\overline{15}}_{D e-m i} \underbrace{6}_{\text {Dhar ma Wèt }} \quad \overline{.5} \underbrace{\overline{61}}_{A-\text { gung }} \underbrace{\overline{31} 2}_{\text {o-bor-ing Sang-ha }}
\end{aligned}
$$

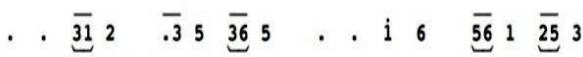

$$
\begin{aligned}
& \text { De-mi Sang-ha De-wan pra su - ci Sra-ma-na }
\end{aligned}
$$

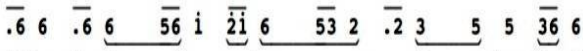

$$
\begin{aligned}
& \text { Rah-yu Beg-ja ka-wu-la nga-ub Sang Bud-dha }
\end{aligned}
$$

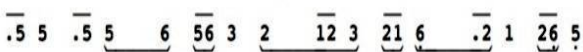

$$
\begin{aligned}
& \text { Rah-yu Beg-ja ka-wu-la nga-ub Sang Dhar-ma }
\end{aligned}
$$

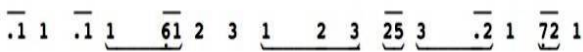

$$
\begin{aligned}
& \text { Rah-yu Beg-ja ka-wu-la nga-ub Sang Sang-ha }
\end{aligned}
$$

\section{Dance Music}

Dance music is one of the supporting elements in a dance performance, where dance music is created after the dance work is formed. So that dance music follows the flow of dance work. Dance music in Pambuka dance notation serves supporters 
in a dance performance in the form of accompaniment such as kidungan, ketawang, and ladrang. Dance music is created or created after the dance work is formed, so that dance music follows the flow of dance work.

\section{Ketoprak}

According to Saptomo (1996: 69), ketoprak is a type of traditional performance that has undergone development since its creation today. Ketoprak consists of several elements, namely lakon, performers, dialogue, acting, fashion, makeup, equipment, and accompaniment music. Badrasanti's literary works are also revitalized in the form of ketoprak performances in the form of narratives and act-dance art (sendratari). One of the plays raised in the performance is Sendratari Tunggak Semi Badrasanti wherein the show raises the historical story of Lasem contained in Badrasanti's book in 1966 and in the presentation of the show using gendhinggendhing as the results of the revitalization of Badrasanti's literary works. This performance was held on Sunday, August 25, 2018, at Wisma Sangga Theravada Indonesia precisely at Jl. Satwa No.4 Pondok Labu, South Jakarta. The performance was held for a thanksgiving event for the award of the 2018 Nusantara Library Award from the National Library.

\section{Wayang.}

According to Bayu Anggoro (2018: 123), wayang is a cultural heritage of ancestors that is estimated to have existed since $\pm 1,500$ years BC. Wayang as one type of show is often interpreted as an unclear or vague shadow, moving around. The faint shadow is interpreted as a picture of a human being.

Badrasanti's literary work in addition to being revitalized in the above performing art forms was also created in the form of a leather puppet show with puppeteer Widodo Brotosejati. The wayang show tells about some of the contents of Badrasanti's literary work conveyed through the show of Wayang Gara-Gara. Some of the gendhing used in the puppet show uses gendhing-gendhing results of the revitalization of Badrasanti's literary work. The performance was held on August 12, 2019 at Saddhagiri Monastery in Njrahi Village, Kecamatan Gunung Wungkal, Kabupaten Pati in the framework of an Anjangsana Budaya (Interfaith) event. The show involves \pm 21 people consisting of dancers, pengrawit or gamelan players, and speakers. The plot in the wayang show broadly conveys the noble advice that exists in Badrasanti's literary work through wayang characters.

\section{The Form of Performance}

Badrasanti's literary works have been revitalized into various forms of art. The form of performance of Badrasanti's literary work in this section only describes the form of Kidung Puji Badrasanti performances laras pelog pathet lima. Here's the explanation:

\section{(1) Karawitan Musical's Elements}

According to Widodo (2018: 32), the musical elements of karawitan referred to in this section include gendhing and balungan gendhing, laras, rhythms and laya, wiled and cengkok techniques, pathet, and dynamics, and musical instruments. A brief description of the elements of the karawitan is as follows:

a) Gendhing and balungan gendhing

The meaning of gendhing generally means the composition of karawitan. In this case, the composition in question is the composition of Javanese karawitan. While the meaning of gendhing, in particular, is the composition of Javanese karawitan in large format, large format in which the size is gendhing kethuk 2 kerep and other gendhing-gendhing whose format is larger such as kethuk 2 arang, kethuk 4 kerep, kethuk 4 arang, kethuk 8 kerep, and kethuk 16 kerep according to Widodo (2018: 60). The size of the gendhing format is determined by the amount of balungan sabetan on each gongan.

Balungan gendhing according to (Widodo, 2018: 63) is the essence of the flow of gendhing songs, in the notation of kepatihan of the composition is written with 
symbols of numbers and dots equipped with other symbols that show the location of ricikan structural that indicates the shape of the composition. Here's the notation of the gendhing balungan on the Kidung Puji Badrasanti laras pelog pathet lima:

Figure 1.5: Balungan Gendhing Kidung Puji Badrasanti

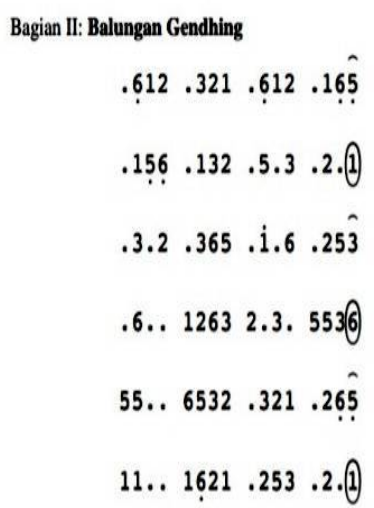

b) Laras

Laras in Javanese culture has three meanings, namely something that is very tasty or beautiful to hear, see, and feel, laras in the sense of tone and tone scale that has a certain frequency, and laras as a slendro and pelog tone scale used in Javanese karawitan (Widdodo, 2018: 64). The laras in that is meant is the laras in the sense of tone and tone scale. Laras used in the process of revitalizing Badrasanti's literary works include laras slendro and laras pelog.

\section{c) Rhytm}

Rhythm or wirama according to (Widodo, 2018: 67) is a fundamental musical element in Javanese karawitan in addition to laras, while the word rhythm itself has the meaning of simple rhythm or looping sounds according to certain patterns in a song, the meaning of rhythm in Javanese karawitan related to tempo gradation and the ricikan of rhythmic and vocal games has five rhythm gradations that are lancar, tanggung, dadi, wiled, and rangkep. Revitalization of Badrsanti's literary work laras pelog pathet lima using dadi rhythms.

d) Laya
Laya has a tempo meaning that indicates the speed of serving gendhing in the same rhythm gradation, broadly speaking the tempo is divided into three, namely: 1) tambahan, alon, langsam, or nglentreh which shows a relatively slow tempo. 2) Shedeng is a relatively medium tempo. 3) Seseg is a relatively fast tempo. Laya used in the performance of Kidung Puji Badrasanti laras pelog pathet lima is a laya nglentreh that shows a relatively slow tempo.

e) Pathet

Pathet is interpreted as diverse as pathet as a theory of gong tone, pathet as the development of melodic themes, pathet as a combination of contours about the task and function of tone, pathet related to work, and pathet as a cool taste atmosphere. In Javanese karawitan composition, laras slendro and laras pelog each have three tones. On the laras slendro, the pathet contents are pathet nem, pathet sanga, and pathet. While the laras pelog, the pathet contents are pathet pelog lima, pathet nem, and pathet goods (Widodo, 2018: 70). Pathet used in Kidung Puji Badrasanti is the laras pelog pathet lima.

f) Dynamics

Dynamics shows the variation in musical elements of gendhing. Diversity of sound colors and vocal rhythms, vocabulary techniques and patterns of play, céngkok, wiled, rhythm, laya, volume, laras, shape and balungan gendhing, pathêt, vocal text, individual and regional karawitan styles are elements of karawitan as a form of dynamics. Its cultivation varies, sometimes contrastingly but proportionately according to the aesthetic rules applicable in Javanese karawitan can build a dynamic musical atmosphere. Dynamic garap, compact, and integrated with unity of ideas is a determinant of the sound quality of karawitan composition (Widodo, 2018: 83). In the context of Kidung Puji Badrasanti the pattern of garap is concerned with the dynamics raised as needed. Cengkok and wiled in the song are already related to the pattern of the song.

g) Musical Instrument 
Kidung Puji Badrasanti, Pl. Five uses gamelan kemanakan musical instruments such as: one pair of kemanakan, kendang bem, and kendang ketipung, slenthem, demung, saron, peking, kenong, kethuk, kempyang, gong.

Gendhing Kidung Puji Badrasanti laras pelog pathet lima using the form of ketawang gendhing structure by paying attention to the pattern of tabuhan of the instrument of the kendang kalih that are kendang bem and kendang ketipung, kethuk, kenong, gong, slenthem, saron, and peking. The formulation of ketawang gendhing Kidung Puji Badrasanti garap kemanakan that is 1 gongan consists of 32 sabetan that there are patterns, 2 tabuhan kenong on the $16^{\text {th }}$ and $32^{\text {nd }}$ sabetan, there are 4 patterns of tabuhan kethuk on the $4^{\text {th }}$ sabetan, 12, 20, and 28. Dynamics in the Kidung Puji Badrasanti pattern of garap kemanakan appears as needed. Cengkok and wiled in the song are already related to the pattern of the song. Laya on Kidung Puji Badrasanti tends to be nglentreh. The rhythm used in the song is the rhythm of dadi.

Figure 1.6: Structural Form of Kidung Puji Badrasanti Laras Pelog Pathet Lima

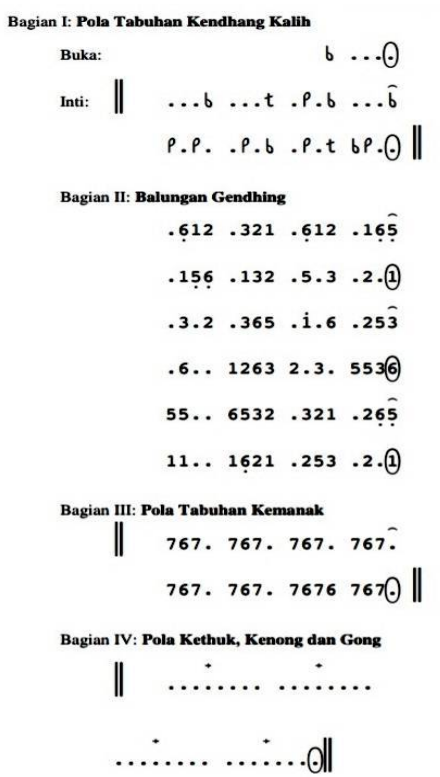

The pattern of garap kemanakan in the Kidung Puji Badrasanti using cakepan or verse contained in the contents of Badrasanti literary works chapter 1 about praise or prayer. Here is an example of notation and cakepan Kidung Puji Badrasanti.

Notation 1.7: Notation Cakepan Kidung Puji Badrasanti Laras Pelog Pathet Lima

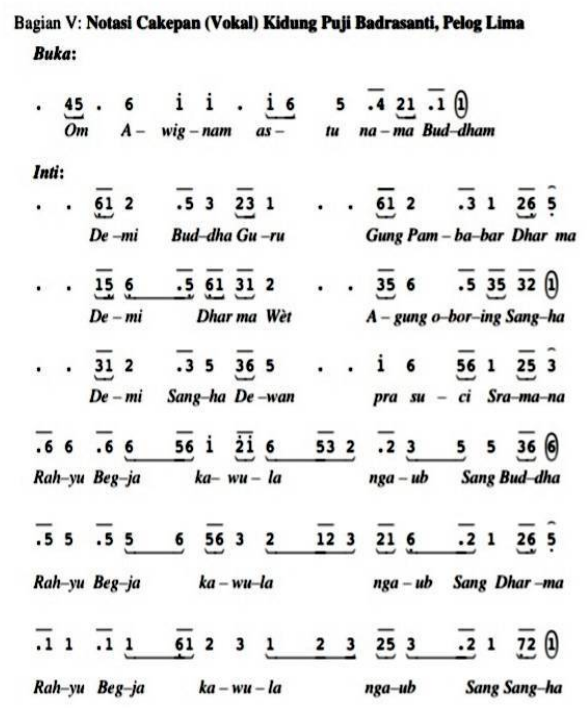

\section{The Form of Presentation}

In order to study a form of performance, it is necessary to know things such as the order of presentation, performers, stage layout, makeup, fashion, sound, and lighting. Here is the description of the presentation of Kidung Puji Badrasanti laras pelog pathet lima.

\section{1) Order of Presentation}

The presentation form of Kidung Puji Badrasanti performance laras pelog pathet lima is presented at each end of the Badrasanti-themed event, the purpose of which is to accompany Buddhists in worship or prayer. The gendhing is presented in five repetitions with the same notation but the cakepan is different follows the theme in each chapter in Badrasanti's literary work.

2) Stage Layout 
Kidung Puji Badrasanti performance of the laras pelog pathet lima is held in a building using stages of varying sizes according to the event and musical instruments used. In the show, the stage uses a white ground floor in the building is covered using blue carpets. Sindhen sits cross-legged using jengkok, sindhen sits in the front row parallel to the self-employed. Pangrawit sat behind sindhen after the gamelan setup formation.

\section{3) Makeup}

In a show, makeup becomes a very important thing and needs to be considered. Makeup has the goal that the face of the karawitan player becomes fresher and unsightly to look at. In the show of Kidung Puji Badrasanti laras pelog pathet lima, sindhen uses makeup in accordance with their respective characters. This makeup includes the use of cleansers, fresheners, foundations, solid powders, sprinkle powder, eye shadow, blush, eyeliner, lipstick, and eyelashes. While the hairdo uses conde.

\section{4) Fashion}

The clothes used by pangrawit on the song performance use sorjan, jarik, and wear blangkon. As for sindhen using kebaya and jarik. The entire clothing worn by the player is clothing provided by Pakarjawi and sindhen.

\section{5) Sound System}

Kidung Puji Badrasanti show requires the use of a speaker to maximize the production of the sound used. The series of supporting tools used is the cabled mic in eleven pieces, two speakers, and one mixer. Kidung Puji Badrasanti presentation collaborated with various audio sound systems from various regions where the event took place.

\section{6) Lighting}

Lighting is an equipment of traditional and modern lamps used for lighting in performing arts (Susetyo, 2007: 4). Every performance of Kidung Puji Badrasanti always uses a variety of light fixtures depending on each theme of the event held. In the presentation of Kidung Puji Badrasanti in the Talk Show Dharmasanti Waisak used neon lights in the event building.

Badrasanti's literary work revitalization activities use four stages according to Rahayu Supanggah (2008). (1) The reconstruction of Badrasanti's literary works needs to be revitalized because the creation stores historical data about various aspects of people's lives in the Lasem area that had been vital, or used by people who embrace Buddhism because of differences in understanding of the literary work had been banned from circulation. The revitalization process was carried out by Wahyudi Agus Riyanto a Buddhist and assisted by Widodo Brotosejati karawitan lecturer at Semarang State University; (2) Re-functionalization is done to develop literary works that have become various forms of art, the process in developing a literary work using karawitan theory, among others, looking at the characteristics of the text of the literary work, making gendhing and balungan gendhing, laras, rhythms, laya, pathet, and dynamics. Through the development of Badrasanti's literary work provides a new function to convey the contents of the literary text that contains many aspects of Javanese Buddhist life to be better known; (3) representation of Badrasanti literary works produced into various forms of artwork such as tembang waosan, garap kemanakan, dance music, kethoprak, and wayang; (4) Reform of Badrasanti's literary work before undergoing revitalization is presented as reading after the revitalization of the literary work undergoes a change in format or form of presentation, Badrasanti literary works are now presented in the form of presentation of works of art such as tembang waosan, and gendhing. The presentation of Badrasanti's literary work uses some aspects that exist in a form of performance, which is the form of composition and the form of presentation. The composition form consists of gendhing and balungan gendhing, rhythm, laya, tempo, pathet, dynamics, and musical instruments. 
While the form of the presentation consists of the flow of the presentation, stage layout, makeup, fashion, lighting, and sound.

\section{CONCLUSION}

Based on the results of research it can be concluded that the literary work is packaged in the form of art performances using aspects of performance including the form of composition and presentation form, in the context of Javanese karawitan using elements in Javanese karawitan such as: gendhing and balungan gendhing, rhythm, laya, laras, pathet, dynamics, and musical instruments. Gendhing and balungan gendhing as in the notation described above, rhythm using dadi rhythm, laya tends to flex or slow, laras using laras pelog, pathet used is pathet lima, dynamics appear according to needs, musical instruments used are a set of gamelan kemanakan which containing: a pair of kemanak, a kendang bem and kendang kalih, slenthem, saron, peking, gong, kenong, and kethuk.

In addition to the composition aspect, there is also a presentation aspect that pays attention to the order of presentation, stage layout, makeup, fashion, sound, and lighting. The presentation of Kidung Puji Badrasanti is presented in every Buddhist event-themed Badrasanti. Badrasanti is served at the end of each event to accompany the prayer, served in five repetitions with the same notation only a different cakepan. The stage layout used is not changing. The makeup used is makeup in accordance with the character of each performer. The clothes used by the karawitan team are clothes belonging to Pakarjawi. The sound system used is a cable mic, two pieces of speakers placed on the left-right side of the stage, and one mixer. The lighting system uses neon in the event room.

\section{REFERENCES}

Andi Pratomo. (2016). Bentuk Musik Iringan Sintren di Desa Kedunguter Kabupaten Brebes. Jurnal Harmonia, 60(1), 1-26. https://doi.org/10.1002/app5.68

Bastomi, S. 1992. "Kebudayaan Apresiasi Pendidikan Seni". Semarang: IKIP Semarang Press.

Bastomi, S. 1992. "Seni dan Budaya". Semarang: IKIP Semarang Press.

Ferial Riezky Herfanda. (2014). BENTUK PERTUNJUKAN MUSIK PERKUSI PAGUYUBAN SAYUNG HORE (PSH) Di SEMARANG. Jurnal Seni Musik, 3(1), 1-9.

Huda, S. (2015). Revitalisasi Musik Iringan Tari Jepin Cangkah Pedang Di Kecamatan Pontianak Barat Kota. Jurnal Universitas Tanjungpura, 33(3), 1-6. https://doi.org/10.1016/j.ssci.2015.04. 023

KBBI. (2020). Kamus Besar Bahasa Indonesia (KBBI) [Online] Available at: http://kbbi.web.id/revitalisasi

Sejati, W. B. (2018). Reaktualisasi Lelagon Dolanan Anak. Semarang: UNNES PRESS

Sumardjo, J. dan S. (1997). Apresiasi Kesusastraan. Jakarta: Gramedia Pustaka Utama.

Susetyo, B. (2005). Perubahan Musik Rebana Menjadi Kasidah Modern di Semarang sebagai Suatu Proses Dekulturasi dalam Musik Indonesia. Jurnal Harmonia, 6(2).

Widodo. (2015). LARAS IN GAMELAN MUSIC 'S PLURALITY. 15(1), 34-45. https://doi.org/10.15294/harmonia.v15 i1.3695

Widodo, T. W. (2017b). Teknologi Komputer dan Proses Kreatif Musik Menuju Revitalisasi Pembelajaran Seni Musik. Promusika, 19(1), 1-6 
Yudarta, I. G., \& Pasek, I. N. (2015).

Revitalisasi Musik Tradisional Prosesi

Adat Sasak sebagai Identitas Budaya

Sasak. Jurnal Segara Widya, 3(1). 